\title{
Application of Linguistics in the Translation of Japanese Texts into Indonesian
}

\author{
Nani Sunarni \\ Fakultas Ilmu Budaya \\ Universitas Padjadjaran \\ nani_sunarni@yahoo.com
}

\begin{abstract}
Exchange of information among countries is now inevitable amidst the rapid development of science and technology at both the local and global levels. Such an exchange is enabled by means of, among others, translation. While books with local Indonesian contents, for example, have been translated into Japanese, books with Japanese contents have also been translated into Indonesian. Various problems are found in the translation process. The Japanese sentence 'Watashi wa gohan o tabemashita', for example, is translated into 'Saya sudah makan'. The original sentence contains the particle 'wa' as a subject marker and the particle ' 0 ' as an object marker. However, no such particles are recognized in the target language. Hence, omission is naturally inevitable. In addition, in the original sentence the suffix '-ta' occurs to indicate past tense. In the translation however, due to the absence of tense, the adverb 'sudah' is used to mark to lexically indicate completion. It is evident from the examples that adequate knowledge of linguistics is required. With regard to this, a study on the application of linguistics in translation processes is needed. The data for the study are Japanese sentences that contain unique linguistic features. Davidson's notion on action research (2004) was consulted during the data analysis. The results indicate that linguistic competence plays an important in the translation of Japanese texts into Indonesian. At the theoretical level, the results of the study can be used as an additional reference on translation and linguistics. In addition, they can also be applied in the teaching of translation and linguistics.
\end{abstract}

Keywords: global, Indonesian, Japanese, local, linguistics

\section{INTRODUCTION}

A language has a universal yet unique nature. It is unique because every language has its own characteristics. Different languages have their own ways of expressing different ideas. Thus, the translation of a text involving two non-cognate languages such as Japanese and Indonesian requires some knowledge about the different characteristics of the pair. The characteristics of a language are inherent in its grammar and the culture in which it is used. The grammatical characteristics of a language are studied in both micro- and macro-linguistics.

In a translation process, whereas micro-linguistics is needed as a basic knowledge about language structure, macrolinguistics is needed as supporting knowledge about related linguistic elements such as figurative language (stylistics) and culture, which support the development of meaning. This is possible because language is part of a culture. Translation is the activity of reproducing a Source Language (SL) message with the closest and most natural possible equivalent in a
Target Language (TL). Here, the word equivalence is related to both meaning and style. In other words, translation is the replacement of a text in an SL with a text in a TL without changing its content level. Content level refers not only to material meaning, idea, or concept but to all information contained in the SL text. This information includes all linguistic forms, including lexical and grammatical meaning, stylistics, expressive nuances, and paralinguistic elements. Thus, adequate knowledge in both Japanese and Indonesian micro- and macro-linguistics is important to prevent difficulties that may arise in the translation of a Japanese text into Indonesian and a translator must conform to certain linguistic norms.

\section{METHOD}

The study used a descriptive method and a connecting-comparing technique. The data consist of Japanese words, phrases, sentences that have unique linguistic features and whose equivalents are not to be found in Indonesian. The data were analysed by using approaches in translation method and linguistics.

\section{APPLICATION OF LINGUISTICS IN TRANSLATION PROCESS}

In translating various types of texts, e.g. written or spoken texts, literary texts, journalistic texts, scientific texts, newspaper articles, academic paper, formal documents, and scientific texts, one always encounters linguistic units. Linguistic units vary from the smallest, namely phoneme, up to larger ones, namely morpheme, word, phrase, clause, sentence, text, and discourse. These elements are the objects of microlinguistics. Yet, a word, sentence, or even text will not occur without a situation. Thus language comes into use because of linguistic, epistemic, physical, and social contexts. These contexts are the concern of macro-linguistics. Understanding of such contexts enable a translator to work produce effective translation in which natural and equivalent translation equivalents are achieved.

\section{1. APPLICATION OF PHONOLOGY IN PHONEME- LEVEL TRANSLATION PROCESS}

Japanese language has a different system of sound from Indonesian. One distinct feature of the Japanese language is that it recognizes long (chooon) and short vowel sounds. The length of a vowel often determines the meaning of a word. Such a feature is not to be found in Indonesian. Thus, vowel 
length is a factor that a translator must take into account when translating a text from Japanese into Indonesian. The following table lists some of words that change meaning due to vowel length.

Table 1: Long and short sounds that mark different meanings in Japanese

\begin{tabular}{|c|c|c|c|}
\hline $\begin{array}{c}\text { Short } \\
\text { vowel }\end{array}$ & $\begin{array}{c}\text { Sample } \\
\text { sentence and } \\
\text { translation }\end{array}$ & $\begin{array}{l}\text { Long } \\
\text { vowel }\end{array}$ & $\begin{array}{c}\text { Sample sentence } \\
\text { and translation }\end{array}$ \\
\hline $\begin{array}{l}\text { [tokei] } \\
\text { 'jam } \\
\text { tangan' }\end{array}$ & $\begin{array}{l}\text { Watashi wa } \\
\text { tokei o hameru } \\
\text { 'saya memakai } \\
\text { jam tangan' }\end{array}$ & $\begin{array}{l}\text { [tookei] } \\
\text { 'statistik' }\end{array}$ & $\begin{array}{l}\text { Imouto wa tookei } \\
\text { o benkyou shite } \\
\text { imasu. } \\
\text { 'Adik perempuan } \\
\text { saya belajar } \\
\text { statistik' }\end{array}$ \\
\hline
\end{tabular}

\subsection{APPLICATION OF PHONOLOGY IN WORD-LEVEL TRANSLATION PROCESS}

Translating a word from an SL will not be difficult if there is a word-level equivalent in the TL. It will be a problem when the SL and TL have totally different systems. In the case of translation from Japanese into Indonesian, pitch accent may be a big problem. One unique feature of the Japanese is pitch accent. The meaning of a word is often determined by its low or high pitch when spoken. In Indonesian, however, pitch accent does not change the meaning. People whose language does not recognize such a feature may have a problem understanding a foreign language in which pitch accent plays an important role in differentiating meaning. In such a situation, non-native speakers of Japanese often rely on context of utterance or sentence to understand certain words. Knowledge about phonology, especially pitch accent, is therefore essential in translation, and, in particular, interpretation of spoken language. The table below lists similar words with different pitch accents.

Table 2: Meaning-differentiating Pitch Accent and Phonetic Proximity in Japanese

\begin{tabular}{clll}
\hline No & Word & Pitch Accent & Meaning \\
\hline 1 & Kouri & {$[$ koūri] } & eceran \\
\hline 2 & Kouri & {$[$ kōōri] } & keuntungan public \\
\hline 3 & Koori & {$[$ kōōri] } & es \\
\hline
\end{tabular}

\subsection{APPLICATION OF MORPHOLOGY IN MORPHEME- LEVEL TRANSLATION PROCESS}

Both Japanese and Indonesian are agglutinative languages. Tenses in Indonesian are signified by lexical markers, namely the words sudah, sedang, and akan, and adverbials of time. In Japanese, however, tenses are signified by bound morphemes, namely suffixes, that are attached to stem words. In the process of translating Japanese tensed verbs, a translator must pay attention to their morphological formation.

Example:

(1) Kanojo wa naka naka kirei datta.
Dia subject particle sangat cantik adalah

(past)

(a)*'Dia sangat cantik'.

(a') '(Dulu) dia sangat cantik'.

Sentence (a) is a word-for-word translation and the sentence indicates no reference to past tense. This is perhaps because the translator failed to notice the grammatical characteristic of Japanese, which marks the pastness of a verb with the suffix $-t a$, which is a bound morpheme. Knowledge in Japanese morphology enables a translator to give a lexical addition by placing an adverbial of time such as in sentence (a').

Apart from the above feature, another distinctive grammatical feature of the Japanese language is the aspect. In Indonesian, aspect is marked lexically by an adverbial of time. However, in Japanese, aspects, particularly the imperative, is marked by the suffix $\sim$ te iru (teiru verb form). A translator therefore should understand the meaning of the suffix in order to produce an equivalent translation such as shown in the example below.

(2) Hiroba de kodomo ga asonde iru Lapangan di anak-anak subject particle bermain (sedang)

(b) *'Anak-anak bermain di Lapangan'

(b') 'Anak-anak sedang bermain di Lapangan'

(3) Tokeiga tomatte iru

Jam particle berhenti berdetak

(c) * 'Jam (sedang) berhenti berdetak'

(c') 'Jam mati' or 'Jam dalam keadaan mati'

(4) Yama ga sobiete iru

Gunung particle menjulang

(d) *'Gunung sedang menjulang'

(d) 'Gunung menjulang'

The translations (b) from (2), (c) from (3), and (d) from (4) are word-for-word translations. Thus the meaning the predicate-verb in the sentences is vague. Such translations may occur due to the translator's failure to observe the meanings of such bound morphemes as the suffix -te iru, which adheres to each of the predicate-verbs above. The suffix - te iru itself in Japanese denotes that an action is "taking place". However, even if, as in the translation of sentences (3) and (4) above, the word "sedang" is added, the Indonesian sentences are still unacceptable. This is because the nature of the verbs in sentences (3) and (4) is different from that of the verb in sentence (2). The verb in sentence (2) is an action verb. Thus, the addition of the word "sedang" is necessary. The verb in sentence (3) is a momentary verb. When a momentary verb is added with the suffix -te iru changes into a stative verb. The insertion of the word "sedang" is thus unacceptable. The use "sedang" in sentence (d') is also incorrect because the verb that ends with the suffix -te iru in the original sentence refers to a natural fact. Ignorance about the concept of aspects in Japanese 
therefore will result in an awkward translation. A translator must understand the entire grammatical elements of the source language.

\section{4. THE APPLICATION OF FIGURATIVE LANGUAGE IN PHRASE-LEVEL AND SENTENCE- LEVEL TRANSLATION PROCESS}

As mentioned earlier, the data studied consist of Japanese sentences that are unique and therefore have no equivalent in Indonesian. However, such sentences are not untranslatable for they still can be translated into Indonesian using various translation techniques.

\section{Example:}

(5) Uso naki

Bohong menangis

'tangisan bohong'

(6) korobanu saki no tsue tidak jatuh ujung particle tongkat

*'Tidak jatuh ujung tongkat'

It is impossible to retain the structure of the phrasal expression "usonaki" and the proverb (6) above in the translation. The result would be unnatural in the target language. Using the technique of stylistic shift, however, a translator can render the expressions into 'air mata buaya' and 'sedia payung sebelum hujan'.

\subsection{THE APPLICATION OF SYNTAX IN TEXT- LEVEL TRANSLATION PROCESS}

Language is an element of culture. Therefore, it is important to take into account the culture of the source language when translating a text into another language. This case is illustrated in the following example.

(7) Mada fumoto no momiji ga asai ga, kono atari no reiki wa mi ni shimiru hodo da.

The sentence consists of two clauses:

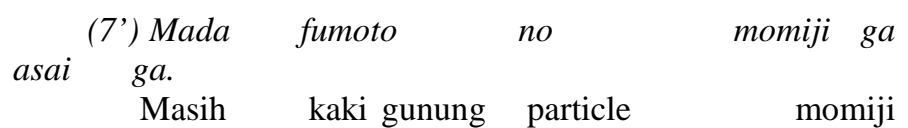
particle subject dangkal tetapi

*'Momiji kaki gunung masih dangkal'

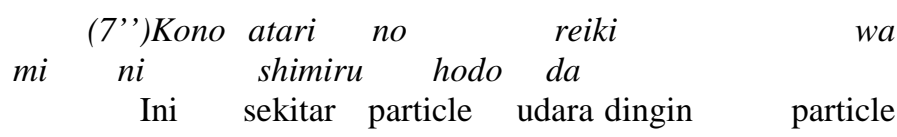
subject badan terhadap meresap hampir adalah

*'Udara dingin di sekitar ini, hampir menusuk badan'

The translations of both clauses are unacceptable because they are word-for-word translation. In order to produce a good translation, particular attention must be given to the cultural word "momiji". Momiji is the name of a specific plant that grows only in Japan. When momiji leaves turn yellow or red, it is a sign that autumn is coming. The word "asai" is also culturally important. The denotative meaning of "asai" is "shallow". However, in order to obtain a natural translation, an analogy is needed. By using analogy and the semantic shift technique, the word can be translated into the phrase "belum terlihat jelas". The phrase mi ni shimiru hodo may be literally equivalent to the expression "seolah-olah meresap dalam tubuh". However, in order to create an equivalent situation in the TL, the stylistic shift technique can be used to produce a better expression "benar-benar sangat menusuk". Here free translation proves to be effective in translating a culturally charged text into Indonesian. The following therefore explicates a more natural translation of the sentence.

Mada fumoto no momiji ga asai ga, kono atari no reiki wa mi ni shimiru hodo da.

'Perubahahan warna dedaunan di kaki gunung yang menandakan awal musim gugur belumlah terlihat jelas, namun udara dingin di sini benar-benar sangat menusuk'

\section{CONCLUSION}

Understanding the structural characteristics of both the SL and TL is first and foremost in translating a text. Then, for language is an element of culture, understanding of the culture of both languages is also important. While the structural characteristic of a language is the concern of micro-linguistics, cultural understanding is part of macro-linguistics. In other words, adequate knowledge about linguistics is required as a basis of competence in translation.

\section{REFERENCES}

Davidson, J. W. 2004. The music practitioner: Research for the music performer, teacher, and listener (pp. 1-9). Aldershot. 